\title{
DEVELOPMENT OF PRIMARY AND BACTERIAL PRODUCTIVITY IN UPWELLING WATERS OF ARRAIAL DO CABO REGION, RJ (BRAZIL)
}

\author{
Wanderson Fernandes de Carvalho ${ }^{1,2}$ \& Eliane Gonzalez Rodriguez ${ }^{1}$ \\ ${ }^{1}$ Instituto de Estudos do Mar Almirante Paulo Moreira (IEAPM) \\ Divisão de Biologia, Departamento de Oceanografia \\ (Rua Kioto, 253, Praia dos Anjos 28930-000 Arraial do Cabo, RJ, Brazil) \\ wanderson_ac@yahoo.com.br \\ ${ }^{2}$ Universidade Federal Fluminense \\ Departamento de Biologia Marinha \\ (Outeiro São João Batista s/n, Morro do Valonguinho, 24001-970 Niterói, RJ, Brazil)
}

\begin{abstract}
A B S T R A C T
A relationship between phytoplankton and bacterioplankton was observed in a laboratory experiment simulating partial and complete upwelling conditions. Primary and bacterial productivity presented a similar pattern, with a three-stage development (growth, peak and decline in production). However, bacterial development stages did not occur simultaneously with the phytoplanktonic development, that is, the highest bacterial production rates occurred in the stages of growth and decline of the primary production, whilst the lowest values of bacterial productivity were simultaneous to the highest phytoplanktonic production stage. Analysis of data obtained in this experiment shows a close relationship between phytoplankton and bacteria, in which these organisms might be competing for inorganic nutrients in some moments, and bacteria might have, as an important source of carbon, the particulate or dissolved organic matter coming from the phytoplankton. Besides that, bacteria might play an important role in the initial stages of phytoplankton blooms, when they might be one of the main conditioning agents of the waters that have just upwelled, allowing the plain phytoplanktonic development.
\end{abstract}

\section{RESUMO}

Relações entre o desenvolvimento fitoplanctônico e bacterioplanctônico foram observadas ao longo do tempo em um experimento de laboratório, simulando condições de ressurgência parcial e completa. As produções primária e bacteriana apresentaram um padrão similar, com três fases de desenvolvimento em águas com algum grau de ressurgência. Entretanto, o momento em que ocorrem as fases é invertido, ou seja, os picos de produção bacteriana ocorrem nas fases de indução (aumento) e declínio da produção primária ao passo que, nas fases de pico de produção fitoplanctônica a produção bacteriana apresenta os menores valores. As análises dos dados obtidos nesse experimento sugerem uma estreita relação entre o bacterioplâncton e o fitoplâncton, onde as bactérias teriam como uma importante fonte de carbono a matéria orgânica particulada e dissolvida proveniente do fitoplâncton. Além disso, as bactérias teriam papel preponderante nas fases iniciais dos "blooms" fitoplanctônicos quando seriam um dos principais agentes condicionadores das águas recém ressurgidas, possibilitando o pleno desenvolvimento do fitoplâncton.

Descriptors: Primary production, Bacterial production, Plankton, Upwelling, Arraial do Cabo, Brazil.

Descritores: Produção primária, Produção bacteriana, Plâncton, Ressurgência, Arraial do Cabo, Brazil.

\section{INTRODUCTION}

Regions in which occur the upwelling of deep waters, rich in nutrients are known by their high biological productivity (Valentin, 1994). This phenomenon is caused by a conjunction of physical and meteorological factors and continental shelf morphology (Valentin, 1994). The Physical-chemical changes caused by the upwelling events in these areas are highly favorable opportunities to the observation of the relationship among several trophic compartments in diverse environmental situations.

Arraial do Cabo region is the point of the Brazilian coast where the main upwelling event 
occurs. In this area the South Atlantic Central Water (SACW) current raises to the surface (Valentin, 1994). The upwelling on this region is remarkable seasonal becoming more often between spring and summer months due to the predominance of east-northeast strong winds (Valentin \& Moreira, 1978).

Arraial do Cabo upwelling can be ecologically divided in three stages: (I) deep waters raise, (II) productive phase (increase of the primary production and phytoplankton bloom), and (III) decline of the bloom (Gonzalez-Rodriguez et al., 1992). The productive stage is only reached one to four days after the upwelling waters reach the euphotic layer. Then the waters warm up and there are more favorable conditions for the phytoplantonic development. However, this stage generally does not happen exactly where the depth waters upwell, in response to the SW flow of the SACW (Lorenzzetti \& Gaeta, 1996).

Considering the factors above and the logistic difficulties to follow SACW flow and measuring the biotic and abiotic parameters, a laboratory experiment was conducted to simulate different degrees of upwelling SACW, in order to observe development of the primary and bacterial production on the three stages of the upwelling and compare these results with the literature.

\section{Methodology}

Study Area and Sampling: water for the experiments was sampled at a $60 \mathrm{~m}$ deep fixed station, located in front of the "Focinho do Cabo" at $23^{\circ} 01^{\prime} \mathrm{S}$ and $42^{\circ} 00^{\prime} \mathrm{W}$ (Fig. 1). This region is the point where the Brazilian coast changes its direction from Northsouth to East-West. It forms a divergence between the coast and the Brazilian Current (BC), resulting in lower pressure zone, favoring deep-water transport up to the surface. Moreover, there is also a change in continental shelf profile (Valentin, 1994). The 50 and $100 \mathrm{~m}$ isobaths get closer to the coast resulting in a higher depth costal area. These factors contribute to the occurrence of South Atlantic Central Water (SACW) upwelling phenomenon that influences strongly this area, which is one of the first sites to feel its effects.

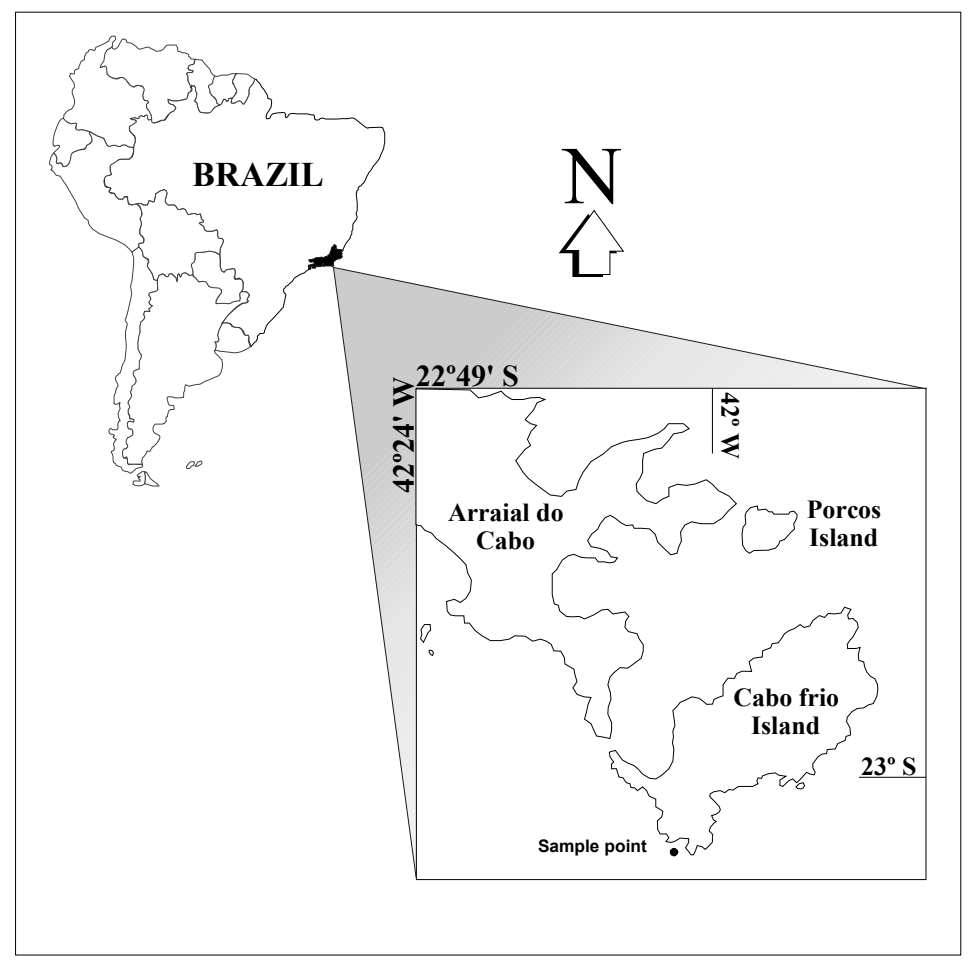

Fig. 1. Area map (sample point). 
Temperature profile was previously determined by CTD launching (SBE-19 SEACAT Profiler). Three hundred liters of water were collected with a 101 VanDorn bottle, 1501 at the surface, $\left(23.6^{\circ} \mathrm{C} ; 35.81 \mathrm{PSU}\right)$. These temperature and salinity are characteristics of the Brazil Current (BC) with some influence of Costal Waters $(\mathrm{CW})$. The other 150 1 were collected at the bottom $\left(50 \mathrm{~m}-13.7^{\circ} \mathrm{C} ; 35.3\right.$ PSU). It was confirmed the presence of the SACW occupying the whole lower layer and producing a strong thermocline at the intermediary layer (Figs 2 and 3). The water was stored in 50-liter bins, painted in black to avoid light penetration. The bins were previously rinsed with distilled water and seawater from the same sampling site and depth before receiving the samples and were protected from the sunlight.

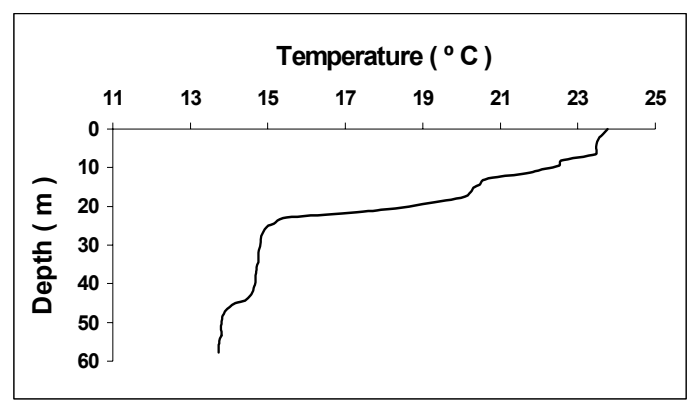

Fig. 2. Temperature profile in the fix station at the moment that water was sampled to perform the laboratory experiments.

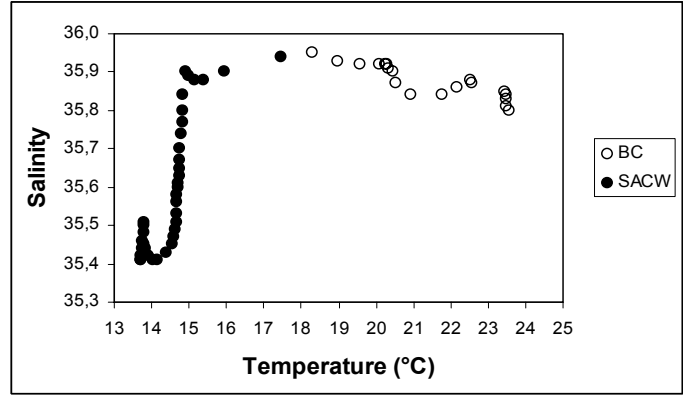

Fig. 3. T-S diagram of the water column in the fix station at the moment that water was sampled to perform the laboratory experiments. Black dots are South Atlantic Central Water $(\mathrm{SACW})$, and white dots are Brazilian Current (BC).

In the laboratory, bottom water was mixed in different proportions with surface water in order to simulate partial and total upwelling events. Three replicates of each mixture, 181 each, were distributed to transparent $201 \mathrm{bins}$, in the following proportions: $0 \%$ (no upwelling) - just pure surface water; $35 \%$ (weak partial upwelling) - 6,3 1 (35\% of the total volume) of SACW mixed to 11,71 ( $65 \%$ of the total volume) of surface water; $75 \%$ (partial upwelling) 13,51 ( $75 \%$ of the total volume) of SACW mixed to 4,51 ( $25 \%$ of the total volume) of surface water; $100 \%$ (total upwelling) - just pure SACW.

The bins containing the replicates of each mixture were preserved in artificially lit shelves with an average intensity of $350 \mu \mathrm{E} \cdot \mathrm{m}^{-2} \cdot \mathrm{s}^{-1}$ inside the bins, determined by a LI-190 SA probe coupled to the LICOR DATALOGGER LI-1000, at a 12:12 h light/dark cycle, at an environment temperature of $19.0^{\circ} \mathrm{C}$ and with no aeration. For seven days, every 24 hours, daily samples were taken for chlorophyll- $a$ and nutrients $\left(\mathrm{NO}_{3-}, \quad \mathrm{NO}_{2-}, \quad \mathrm{NH}_{4}+\right.$ and $\left.\mathrm{PO}_{4}{ }^{3-}\right)$ dosage and determination of primary production (PP) and bacterial production $(\mathrm{BP})$ rates. Before sampling, each replicate was agitated 10 times.

The first experiment samples (T0) were separated before the distribution of the mixtures in each replicate, in order to obtain an overview of the parameters to be estimated during all the period, before the confinement of the mixtures in controlled conditions. Primary production rate was daily determined by the radioactive carbon assimilation technique (Steeman Nielsem, 1952) and described by Strickland \& Parsons (1972). The samples (125 ml two replicates and a blanc) were inoculated with 10 $\mu \mathrm{Ci}$ of ${ }^{14} \mathrm{C}\left(\mathrm{Na}_{2}{ }^{14} \mathrm{CO}_{3}\right)$ and incubated for $4 \mathrm{~h}$ in similar conditions to the bins. Samples were filtered through Millipore HA - filters (no acidified) and then put in glass scintillation vials with Insta-Gel XF (Packard) scintillation cocktail. The samples were analyzed, after 24h, in a Packard Tricarb 1600 liquid scintillation counter. Bacterial production was determined by the leucine isotope assimilation technique (L-[4.5-3H] described by Smith and Azam (1992). $5 \mu$ of leucine (Amersham TRK 510 Specific Activity $=29.4 \mathrm{Ci}_{\mathrm{mmol}}{ }^{-1}$, Final Concentration $=20 \mathrm{nM}$ ) were added to $1.7 \mathrm{ml}$ of the sample and incubated for one hour in the dark. Incubation was terminated by the addition of TCA $(90 \%)$ to the incubation vials. Dissolved leucine was removed from the incubations by washing with $5 \%$ TCA and successive centrifugation $(13000 \mathrm{rpm}$, $10 \mathrm{~min}$ ). Scintillation cocktail (Insta-Gel XF, Packard) was added to the vials and radioactivity was measured in a liquid scintillation counter (Tricarb Packard 1600). Nutrient concentrations were determined by the methods described by Strickland \& Parsons (1972) and chlorophyll- $a$ and pheopigments concentrations by Richard and Thompson (1952) spectrophotometric method and SCOR-UNESCO equations (1996). 


\section{RESULTS}

Stratification shown by the temperature profile (Fig. 2) was reflected in the nutrients concentration, especially $\mathrm{NO}_{2}{ }^{-}, \mathrm{NO}_{3}{ }^{-}$and $\mathrm{PO}_{4}{ }^{3-}$ (Table 1$)$, confirming the presence of the SACW at the bottom.

Table 1. Nutrients concentration at the depths sampled (surface and bottom).

\begin{tabular}{lcccc}
\hline \hline \multicolumn{1}{c}{ Sample } & $\mathbf{N O}_{2}{ }^{-}$ & $\mathbf{N O}_{3}{ }^{-}$ & $\mathbf{N H}_{4}{ }^{+}$ & $\mathbf{P O}_{4}{ }^{3-}$ \\
Surface & 0,01 & 0,83 & 1,22 & 0,12 \\
Down & 0,30 & 12,90 & 1,41 & 0,99 \\
\hline
\end{tabular}

The four mixtures $(0,35,70$ and $100 \%)$ presented a similar pattern for phytoplankton and bacteria development, as well as for nutrient concentration. The highest variations in the pattern occurred within the first 72 hours of the experiment. The $0 \%$ replicates showed a slightly different trend compared to the other mixtures as a result of the lower nutrient concentration in these replicates (Figs $4 \mathrm{~A}, \mathrm{~B}$, $\mathrm{C}$ and $\mathrm{D})$. These observations are regarded to the distribution of these parameters with time, not to the absolute values in each mixture.

Concerning to the nutrient concentration the four mixtures presented a distribution in two stages: stability stage, from the beginning of the experiment (T0) up to 72 hours (T3) and the depletion stage, hanging from T4 (96 hours) to the end of the experiment (T7). It is important to notice that this represented the general pattern, however, nutrient depletion after 48 hours was much stronger in the $35 \%$ replicates than in the $70 \%$ or $100 \%$ (Fig. $4 \mathrm{~A}$, $\mathrm{B}$ and $\mathrm{C}$ ). Only Ammonia did not follow this pattern. Its concentration varied slightly around $1 \mu \mathrm{mol} .1^{-1}$ in the four mixtures during the 168 hours of the experiment.

Bacterial and primary production also presented similarity in their development pattern. Three stages may be identified in BP: the first increased in production with an average value of 0.09 $\mathrm{mgC} \mathrm{m} \mathrm{m}^{-3}( \pm 0.20)$, within the first 48 hours in all mixtures. In the second stage the highest production rate was recorded after 72 hours. Only the $0 \%$ mixture replicates showed a different pattern. Their production increase stage took place in the first 24 hours (T1). Production decline only occurred in the other mixtures after 72 hours (T3). However, within this term (T3 to T6) the four mixtures again presented an identical general pattern with a minimum BP rate $(5.78 \pm 0.56$ $\mathrm{mgC} \mathrm{m}^{-3} \mathrm{~h}^{-1}$ ) and the beginning of a new production increase stage within the last 24 hours in every replicate (Fig. 5 A, B, C and D).
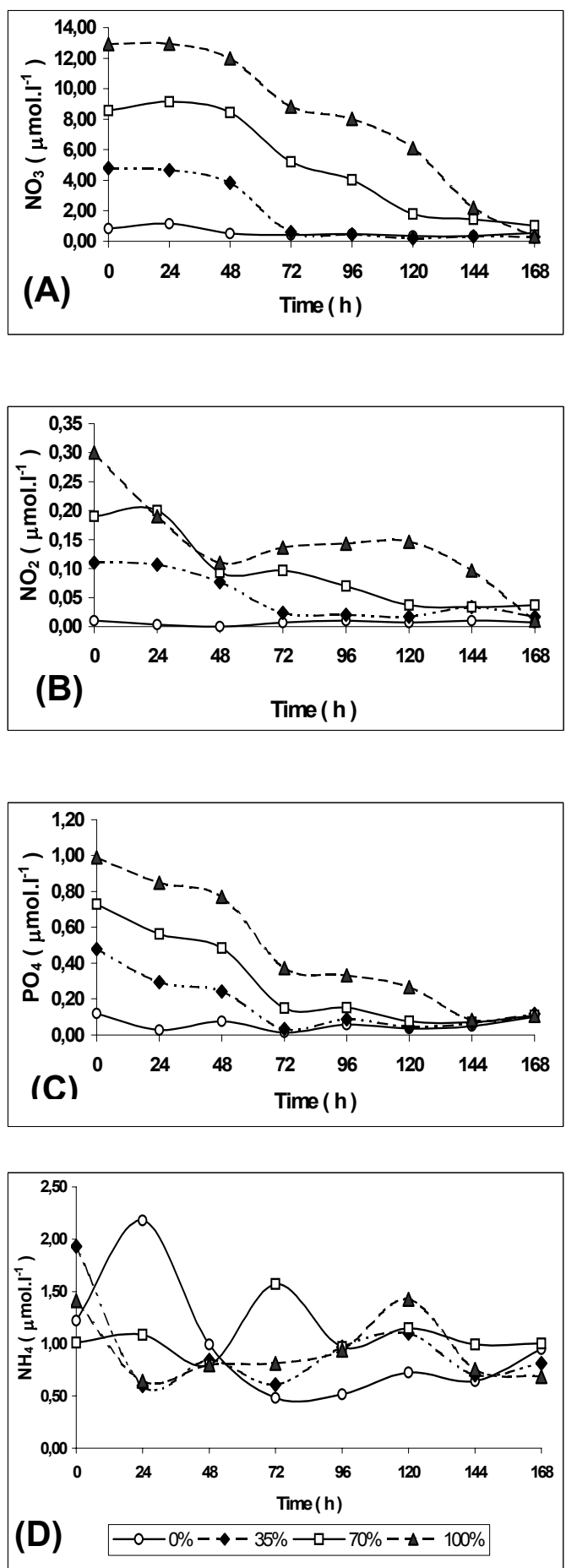

Fig. 4. Development of nutrient ((A) Nitrate; (B) Nitrite; (C) Phosphate and (D) Ammonia) concentrations $\left(\mu \mathrm{mol}^{1-1}\right)$, in the four treatments $(0,35,70$ and $100 \%)$, along of the time. 

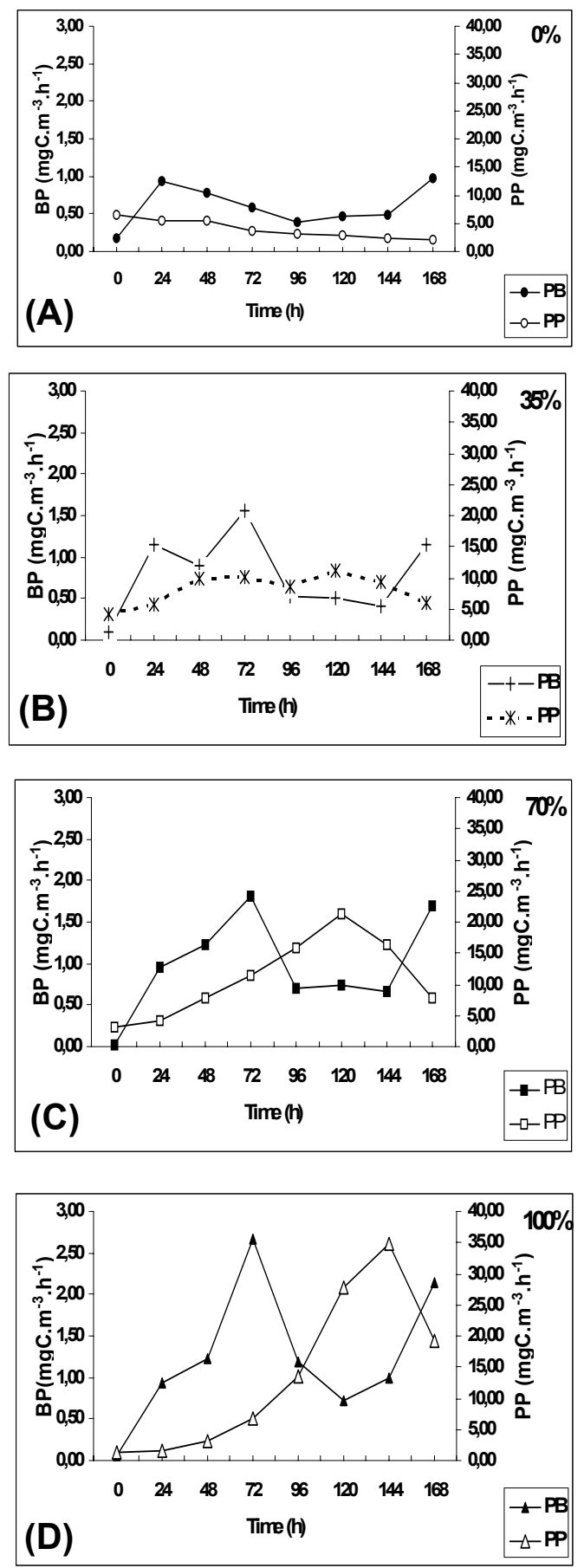

Fig. 5. Development of both Bacterial Production (BP $\mathrm{mgC} . \mathrm{m}^{-3} \cdot \mathrm{h}^{-1}$ ) and Phytoplankton Production (PP - mgC.m ${ }^{3} \cdot \mathrm{h}^{-1}$ ) rates, in the four treatments: (A) $0 \%$; (B) $35 \%$; (C) $75 \%$ and (D) $100 \%$, along of the time,
In a similar way to BP, primary production also presented a three-stage development pattern. In the first stage, production rate increased gradually, though the duration of this stage was different for each mixture. In the $0 \%$ replicates there was no production increase stage in the first 48 hours, the PP rate remained stable $\left(5,78 \pm 0,56 \mathrm{mgC} \cdot \mathrm{m}^{-3} \cdot \mathrm{h}^{-1}\right)$ during this period (Fig. 5A). This production rate stability corresponded to the second stage of the phytoplankton development. The third stage corresponded to the steady decline of production through the end of the period. In the $35 \%$ replicates could be noticed the three PP stages (Fig. 5B). In these samples production rate increased in the first 48 hours remained stable to $\mathrm{T} 5(120 \mathrm{~h})$ and then decreased to the production level observed at the beginning of the experiment. In the $70 \%$ mixture a long stage of steady production increase was observed between $\mathrm{T} 0$ and $\mathrm{T} 4$, the maximum production reached at $\mathrm{T} 5(120 \mathrm{~h})$ and entered in the decline stage in the last 48 hours (Fig. 5 C). The early stage of PP development in $100 \%$ mixture was slightly different from the other mixtures. After a period of slow PP increase (T0 to T4), an exponential increase occurred with the highest $\mathrm{PP}$ rate at T6 (144 h), followed by the decline stage in the last 24 hours (Fig. 5D).

The distribution of Chlorophyll- $a$ concentrations was the same observed for PP. The largest difference in the distribution of these two parameters was observed in the last 48 hours of the experiment. Within this interval, PP decreased in all the mixtures, while chlorophyll concentrations remained stable. Only in the $70 \%$ mixture was possible to notice a decrease in chlorophyll concentration between $\mathrm{T} 5$ and $\mathrm{T} 6$, although it also stabilized around $5,18( \pm 0.16) \mathrm{mgChl}-\mathrm{a} \cdot \mathrm{m}^{-3}$ in the last 24 hours (Fig. 6).

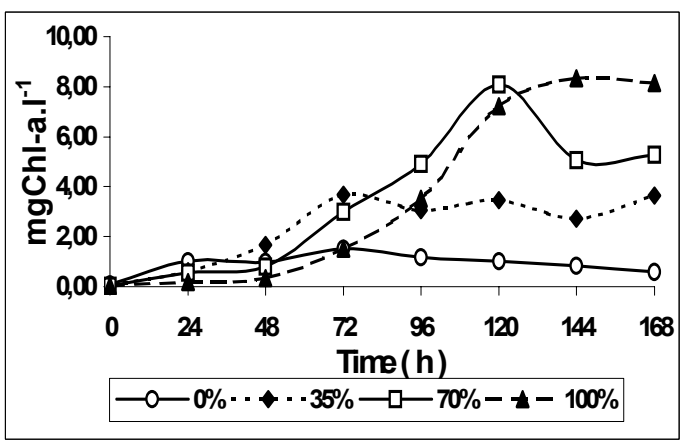

Fig. 6. Development of chlorophyll- $a$ concentration $\left(\mathrm{mg} . \mathrm{m}^{-3}\right)$, in the four treatments $(0,35,70$ and $100 \%)$, along of the time. 
The average of BP:PP ratio in the $0 \%$ replicates in the whole period was $15 \%$. The average for BP:PP ratio in the two stages of phytoplankton development were: $10.89 \%$ in increase stage and peak and $21 \%$ in the decline stage. In this mixture BP was significantly correlated to $\mathrm{NO}_{3}^{-}, \mathrm{NO}_{2}^{-}$and to $\mathrm{PP}$ with $93 \%$ explanation of its variation (Table 2 ) given by the multiple regression model adjusted with these three variables.

The average BP:PP ratio for the 35,70 and $100 \%$ mixtures was very similar (Table 3 ), but it is possible to identify some differences in this relationship observing the different phytoplanktonic development stages. During the PP increase stage, BP:PP ratio remained similar in the three mixtures (11, 11 and $13 \%$ respectively). However, during the stage which the highest primary production rates were recorded, coincidently with the lower BP rates $(\sim 1$ $\left.\mathrm{mgC} \mathrm{h}^{-1} \mathrm{~m}^{-3}\right)$, the $35 \%$ mixture presented the highest BP:PP ratio $(9 \%)$ while 70 and $100 \%$ mixtures were lower $(3.5$ and $3 \%)$. The values of this ratio started growing again $(10,10$ and $11 \%)$ in the PP decline stage.

Table 2. Summary of the multiple regression analyses for the BP as dependent variable, in the four treatments and in the general data set.

\begin{tabular}{|c|c|c|c|c|c|c|c|c|c|}
\hline $\begin{array}{l}\text { Treatment } \\
\text { (n) }\end{array}$ & $\mathbf{R}$ & $\mathbf{R}^{2}$ & $\mathbf{F}$ & $\mathbf{P}$ & $\begin{array}{l}\text { Variables in } \\
\text { the model }\end{array}$ & BETA & $\begin{array}{c}\text { SE } \\
\text { of } B E T A\end{array}$ & $\mathbf{t}$ & $\mathbf{p}$ \\
\hline $\begin{array}{c}0 \% \\
(8)\end{array}$ & 0,97 & 0,93 & $(3,4)=18,45$ & 0,008 & $\begin{array}{c}\mathrm{PP} \\
\mathrm{NO}_{2}^{-} \\
\mathrm{NO}_{3}^{-}\end{array}$ & $\begin{array}{l}-0,91 \\
-0,89 \\
0,64\end{array}$ & $\begin{array}{l}0,18 \\
0,14 \\
0,17\end{array}$ & $\begin{array}{r}-5,09 \\
-6,35 \\
3,76\end{array}$ & $\begin{array}{l}0,01 \\
0,00 \\
0,02\end{array}$ \\
\hline $\begin{array}{c}35 \% \\
(8)\end{array}$ & 0,74 & 0,55 & $(1,6)=7,22$ & 0,036 & $\mathrm{NH}_{4}^{+}$ & $-0,74$ & 0,28 & $-2,69$ & $\mathbf{0 , 0 4}$ \\
\hline $\begin{array}{c}70 \% \\
(8)\end{array}$ & 0,92 & 0,84 & $(3,4)=7,048$ & 0,045 & $\begin{array}{r}\mathbf{P O}_{4}{ }^{3-} \\
\mathbf{P P}\end{array}$ & $\begin{array}{l}-2,45 \\
-1,18\end{array}$ & $\begin{array}{l}0,58 \\
0,34\end{array}$ & $\begin{array}{l}-4,24 \\
-3,43\end{array}$ & $\begin{array}{l}0,01 \\
0,03\end{array}$ \\
\hline $\begin{array}{c}100 \% \\
(8)\end{array}$ & 0,93 & 0,87 & $(3,4)=9,09$ & 0,029 & $\begin{array}{c}\mathbf{P O}_{4}{ }^{3-} \\
\mathbf{P P}\end{array}$ & $\begin{array}{l}-1,47 \\
-1,36\end{array}$ & $\begin{array}{l}0,51 \\
0,38\end{array}$ & $\begin{array}{l}-2,90 \\
-3,62\end{array}$ & $\begin{array}{l}0,04 \\
0,02\end{array}$ \\
\hline $\begin{array}{c}\text { General } \\
\text { data } \\
(32)\end{array}$ & 0,71 & 0,51 & $(5,26)=5,39$ & 0,002 & $\begin{array}{c}\mathrm{NO}_{3}^{-} \\
\mathrm{CHL}-\mathrm{a} \\
\mathrm{PO}_{4}{ }^{3-} \\
\mathrm{PP}\end{array}$ & $\begin{array}{r}2,09 \\
1,04 \\
-1,53 \\
-0,88\end{array}$ & $\begin{array}{l}0,47 \\
0,34 \\
0,50 \\
0,36\end{array}$ & $\begin{array}{r}4,43 \\
3,05 \\
-3,06 \\
-2,49\end{array}$ & $\begin{array}{l}0,00 \\
0,01 \\
0,01 \\
0,02\end{array}$ \\
\hline
\end{tabular}

Table 3. Results of PB:PP ratio: in the general data set and in the different phytoplankton development phases, for the four treatments $(0,35,70$ and $100 \%)$.

\begin{tabular}{lcccc}
\hline \hline & \multicolumn{4}{c}{ Treatments } \\
\cline { 2 - 5 } \multicolumn{1}{c}{ Average PB:PP ratio ( \% ) } & $\mathbf{0 \%}$ & $\mathbf{3 5 \%}$ & $\mathbf{7 0 \%}$ & $\mathbf{1 0 0 \%}$ \\
\hline General & 15,26 & 9,68 & 8,94 & $\mathbf{9 , 1 8}$ \\
PP Increase Phase & - & 10,82 & 11,23 & $\mathbf{1 2 , 5 8}$ \\
PP Stable or Highest Phase & 10,89 & 8,69 & 3,48 & $\mathbf{2 , 8 4}$ \\
PP Decline Phase & 20,61 & 10,15 & 9,77 & $\mathbf{1 1 , 1 5}$ \\
\hline
\end{tabular}


Average values did not reflect very well the BP:PP ratio variation, even when they were regarded in relation to the phytoplankton development stages. A daily observation of BP: PP ration showed responses of bacterial productivity to primary production variations that cannot be noticed by the average. The daily variation pattern in the BP:PP ration was very similar between the mixtures with some influence of bottom water: small percentage at the beginning of the experiment (T0), highest values between 24 and 72 hours (T1 and T3), decrease between 96 and 144 hours (T5 and T6) and the beginning of a new increase in the last 24 hours. In the $0 \%$ mixture (with surface water only) the ratio was stable between $\mathrm{T} 1$ and $\mathrm{T} 5$ with a recovery in the ratio increase during the last 48 hours (Fig. 7). The absolute values of this variation are in Table 4.

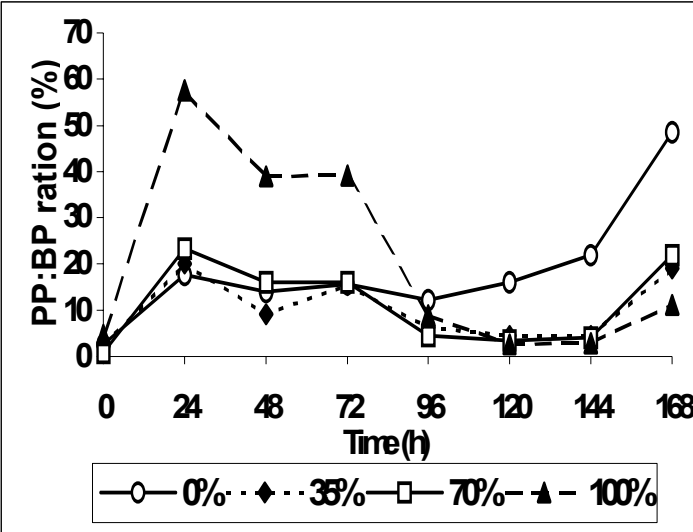

Fig. 7. Daily PB:PP ratio, in the four treatments $(0,35,70$ and $100 \%$ ), a long of the time.

Table 4. Daily PB:PP ratio for the four treatments $(0,35,70$ and $100 \%$ ).

\begin{tabular}{lcccc}
\hline \hline & \multicolumn{4}{c}{ PB:PP Ratio } \\
& \multicolumn{4}{c}{ Treatments } \\
\hline \multicolumn{1}{c}{ Time } & $\mathbf{0 \%}$ & $\mathbf{3 5 \%}$ & $\mathbf{7 0 \%}$ & $\mathbf{1 0 0 \%}$ \\
\hline T0 & 2,70 & 2,26 & 0,82 & 4,66 \\
T1 (24 h) & 17,56 & 20,04 & 23,33 & 57,53 \\
T2 (48 h) & 13,92 & 9,09 & 16,00 & 38,88 \\
T3 (72 h) & 15,63 & 15,39 & 15,97 & 39,21 \\
T4 (96 h) & 12,18 & 6,20 & 4,42 & 8,87 \\
T5 (120 h) & 16,08 & 4,51 & 3,47 & 2,57 \\
T6 (144 h) & 21,98 & 4,43 & 4,05 & 2,83 \\
T7 (168 h) & 48,42 & 19,05 & 21,98 & 11,16 \\
\hline
\end{tabular}

The multiple regression analyses results, for the $\mathrm{BP}$ as dependent variable, showed a negative relationship with $\mathrm{PO}_{4}{ }^{3-}$ and $\mathrm{PP}$ in the replicates with high influence of upwelling water (70 and $100 \%$ ), presenting an explanation higher than $80 \%(\mathrm{p}<0,05)$ in the $\mathrm{BP}$ variation (Table 2). For the $35 \%$ mixture replicates, the BP explained variation was $55 \%$ $(\mathrm{p}<0.05)$, including only $\mathrm{NH}_{4}+$ in the model (Table 2$)$. Statistical analyses results were obtained taking into account only the data set of each mixture alone. In order to obtain an overview of the influence of each estimated factor on the BP with different values, all the four data sets were gathered in a single matrix and underwent a multiple regression analysis. The explanation for the BP variation under variable conditions of nutrients concentration and phytoplankton biomass production was $51 \%(\mathrm{p}<0.05)$. The following parameters were included in the model: $\mathrm{NO}_{3}{ }^{-}$and Chl-a with positive correlation, and $\mathrm{PO}_{4}{ }^{3-}$ and PP with negative correlation (the same standard of relationship of the 70 and $100 \%$ treatments data Table 2).

\section{Discussion}

The presented BP rates were higher than the rates verified in in situ experiments in this same region (Carvalho, unpublished data). The difference is certainly due to stable conditions of temperature, salinity and absence of predation in the laboratory conditions (Ferguson et al., 1984). They noticed that incubations in recipients, marine bacteria present an increase in number, in average cell volume, in amino acids fixation rates (protein synthesis) and in the percentage of viable cells with time. Bacterial cells that would be inactive, or growing slowly in natural conditions, might become extremely metabolically active in controlled conditions favorable to the growth (Sherr et al., 1999). It would be necessary a better understanding of how cells activate their specific metabolism in incubation conditions and compare to in situ estimates in the same systems in order to provide a coherent interpretation of these experiments. Based on $\mathrm{BP}$ rates observed in the four mixtures, it is possible that changes may have occurred in the metabolic activities of inactive bacteria since the hourly production rate increased from an average of $0.06 \mathrm{mgC} \cdot \mathrm{m}^{-3} \cdot \mathrm{h}^{-1}$, at the beginning of the experiment (T0) to $1 \mathrm{mgC} \cdot \mathrm{m}^{-3} \cdot \mathrm{h}^{-1}$ in the first 24 hours (Fig. $5 \mathrm{~A}, \mathrm{~B}$, $\mathrm{C}$ and $\mathrm{D}$ ) in all mixtures. However, as a mean of comparison the experiment had seemed to be efficient, considering that both phytoplankton and bacterioplankton cells were taken from the same place and then submitted to the same growth conditions in the lab.

The relative stability of the BP:PP ratio seen in the $0 \%$ mixture during the early 120 hours may be explained by the small variation of PP, especially in 
the early 72 hours and of the BP steadiness. The increase in bacterial production between $\mathrm{T} 0$ and $\mathrm{T} 1$ could have been supported by organic matter released by the phytoplanktonic (Malinsky-Rushansky \& Legrand, 1996) and by $\mathrm{PO}_{4}{ }^{3-}$ and $\mathrm{NO}_{2}{ }^{-}$. This approach is supported by the observation that there was an increase in $\mathrm{NO}_{3}{ }^{+}$concentration while a $\mathrm{PO}_{4}{ }^{3-}$ concentration decreased followed by a maximum of $\mathrm{BP}$ in $\mathrm{T} 1$. The organic compounds excreted by algae cells during photosynthesis might be an important source of substrate for bacterial and consequently ammonia regeneration (Le Corre et al., 1996). The increase in $\mathrm{NH}_{4}{ }^{+}$concentration might have occurred as a result of the degradation of organic matter from the phytoplanktonic by bacteria while $\mathrm{PO}_{4}{ }^{3-}$ was being absorved.

The particulate and dissolved organic matter resulting from death and disruption of phytoplanktonic cells in the PP decline stage would be responsible for the bacterial production recovery in the last 24 hours (Fuhrman et al., 1980; Ducklow et al., 1993; Romam et al, 1995) showed by negative correlation between BP and PP. The nitrogen source necessary to the protein synthesis might have been $\mathrm{NO}_{2}$ - as suggested by negative correlation with $\mathrm{BP}$, since this nutrient is uptake by bacteria whatever phosphorous concentration (Thingstad et al., 1999), and because its concentrations remained constantly low in this mixture for all the experiment. Another nitrogen source for the bacteria synthesis might have been $\mathrm{NH}_{4}+$, which was not significantly correlated to BP. Ammonia may be produced and uptake simultaneously by bacteria (Le Corre et al., 1996) and on account of it $\mathrm{NH}_{4}^{+}$ concentrations remained virtually constant between $\mathrm{T} 3$ and $\mathrm{T} 7$.

The BP:PP ratio in $0 \%$ mixture showed that in absence of upwelling conditions, bacterioplanktonic production in Arraial do Cabo region stood for $31 \%$ of the hourly phytoplanktonic production, assuming a growth efficiency of $50 \%$. Considering that bacterial production is not interrupted at night and that night production is similar to the daily production (Carvalho, unpublished data), this ratio may reach $61 \%$ of the daily primary production. If the same pattern is used to the values observed during the phytoplankton development stages, it is possible to achieve an average ratio of $44 \%$ in the stability stage, what is consistent with the daily BP:PP ratio higher than $40 \%$ proposed by Ducklow \& Hill (1985). This BP:PP average ratio was proposed for open ocean warm surface waters, characterized by low biomass, low nutrient and low production levels. And if the same extrapolation is applied for the average ratio observed in the PP decline stage this value increase to $82 \%$, as suggested by $\mathrm{Li}$ et al. (1993) for blooms decline stages.
The distribution of $\mathrm{PB}: \mathrm{PP}$ ratio through the time was similar for the three mixtures representing upwelling presence (partial and total). A similar explanation proposed for the $0 \%$ experiment can be given here. In other words, the $\mathrm{PB}$ as well as PP demonstrated same pattern of development (with three phases) along of the time, although time duration of each phase was different between primary production and bacterial production.

Different correlations between BP and nutrients in each mixtures support the idea of the extreme versatility of bacteria in supplying their nutritional needs in different situations (Pomeroy, 1992). Almost complete depletion of $\mathrm{PO}_{4}{ }^{3-}, \mathrm{NO}_{3}{ }^{-}$and $\mathrm{NO}_{2}^{-}$in the early 72 hours of the experiment in the $35 \%$ mixture suggests that there was competition for these nutrients between bacteria and phytoplankton (Tarapchak \& Moll, 1990), since both had their increase stages within this interval.

The correlation between $\mathrm{BP}$ and $\mathrm{NH}_{4}^{+}$ highlighted by the statistical analysis suggests that bacteria might have used this nutrient as a main source of nitrogen (Le Corre et al, 1996) especially after the depletion of $\mathrm{NO}_{3}{ }^{-}$and $\mathrm{NO}_{2}{ }^{-}$after 72 hours and also in the last 24 hours when bacterioplankton recovered increase in production.

The recovering of the $\mathrm{BP}$ increase in the last 24 hours can be explained by an organic matter input originating from phytoplankton, since it was in this interval that was observed the decline of PP in all experiments (Fig. 4). The bacteria could utilize the nitrogen available forms (e.g. ammonium) for protein synthesis. The $\mathrm{PO}_{4}{ }^{3-}$ might be a limiting factor since the efficient uptake of nitrogenous forms, principally $\mathrm{NO}_{3}{ }^{-}$, depends on the $\mathrm{PO}_{4}{ }^{3-}$ concentration (Fuhrman et $a l ., 1980)$ and on the quality of available organic matter in the environment (Kirchman et al., 1993). This conclusion is supported by the results of the analysis that considered the data set of the four experiments simultaneously (Table 3 ).

The relationship among nutrients, PP and BP can be summarized through the BP:PP ratio. In a general average $18 \%$ of the carbon fixed by phytoplankton during the hours of light is consumed by bacteria. It is possible to estimate that more than $40 \%$ of the primary production would pass through the heterotrophic bacteria compartment with a 24 hours period as it has been suggested by many authors (Joiris et al, 1982; Ducklow \& Hill, 1985; McManus \& Peterson, 1988; Li et al., 1993; Sorokin et al., 1996; Thingstad et al., 1996).

Comparing the data of the BP:PP ratio in the mixtures with bottom water influence to the primary production development stages, we noticed that the pattern is similar to that suggested in the literature for spring blooms events, i.e., in the early stage and in the exponential growth of the bloom, BP:PP ratio remains 
below $10 \%$. In the stable stage the percentage can vary from 5 to $20 \%$ and may be higher than $50 \%$ in the decline stage ( $\mathrm{Li}$ et al., 1993). Our results for the decline stage did not achieve values higher than $50 \%$. However, it was not possible to extend the experiment for enough time to follow up this stage, since the decline was only noticed in the last 24 hours of the experiment, when chlorophyll concentration was still stable, suggesting that only part of the organic matter was available and most of it had not become available yet. We believe that bacterial production would reach the values suggested in the literature, as a result of the trend of the distributions and of the pattern observed in the $0 \%$ treatment. Although the amount of organic matter and nutrients in this treatment had been lower, there was almost a total decrease of PP and chlorophyll concentrations, followed by a significant increase in the BP:PP ratio.

It was possible to notice in the 70 and, mainly in the $100 \%$ mixture a pattern of phytoplankton response to the upwelling events, common in this region. Primary production and chlorophyll concentration peaks occur normally two to four days after the beginning of the upwelling in waters away from the coast (Valentin, 1994). In the place and moment when the upwelling is more intense, primary production is low, since low biomass phytoplankton did not have enough time to reproduce (Valentin, 1994). For the phytoplankton begin an exponential growth the upwelled waters must undergo a conditioning, i.e., chelators substances that turn metals in the environment into forms that can be used by phytoplankton cells must be generated (GonzalezRodriguez, 1991). Only after this conditioning period upwelled waters become productive (GonzalezRodriguez et al, 1992), generally away from the coast. McManus \& Peterson (1988) noticed a similar pattern in a coastal upwelling system in the central coast of Chile. In the active upwelling stage phytoplanktonic production is low and bacterial production is high, as a result BP:PP ratio is very high. As the stratification occurs and consequently the water conditioning, bacterial activity decreases simultaneously to the increase in primary production and the BP:PP ratio decreases strongly. The same productivity development patterns observed in Arraial do Cabo and Chile was also notice by Vinogradov \& Shushkina (1978) and Sorokin \& Mikheev (1979) in Peru's upwelling system. Those authors suggested that the upwelled waters go through a heterotrophic and an autotrophic stage. The results of the $100 \%$ mixture, which stood for a complete upwelling, showed this pattern with a water induction period, when bacteria showed an intense activity achieving a proportion relative to PP of 39 to $60 \%$. It might correspond to the upwelling heterotrophic stage, decreasing to a minimum threshold noticed in all the mixtures at the moment the phytoplankton starts to develop exponentially, autotrophic stage. This pattern was also observed in a winter experiment (Carvalho, unpublished data), when the PP peaks occurred one day after the maximum $\mathrm{BP}$ rate.

It was the first time that bacterial activity was estimated in the Arraial do Cabo upwelling region. These observations suggest that bacteria might be the agent or one of the agents of the organic conditioning of upwelled waters and as a result provides conditions for phytoplankton growth. This hypothesis would add to the bacteria one more important role in the dynamics of the marine phytoplankton. Besides converting dissolved and particulate organic matter in viable organic carbon and acting as a link between this carbon and the trophic web. Moreover, bacteria would also have the role of inducing the medium to favorable conditions to phytoplanktonic production. It might contribute to assure the relationship between phytoplankton and bacterioplankton, suggesting that this relation would not be limited only to competition for nutrients and the uptake of organic carbon fixed by phytoplankton.

Based on the presented results, it is possible to conclude that there was a close relationship between bacterioplankton and phytoplankton, mediated by the organic matter released directly or indirectly by phytoplankton. Bacterioplankton might be one of the important sources of particulate organic matter for the region's trophic chain. Also the steadiness of zooplanktonic biomass recorded in the area might be supported mainly by the microheterotrophic bacterivorous, especially during periods of upwelling absence and at the end of phytoplanktonic blooms. Valentin (1984) reported that, in the areas of upwelling dilution and increasing oligotrophy, zooplankton comprises mostly eventual and strict carnivorous. It suggests that nutrients depletion leads to a decline in phytoplankton, its organic matter is fixed by bacteria (Li et al., 1993) which are consumed by ciliates, microflagellates and other phagotrophic protists (Linley et al, 1983; Suzuki, 1999) and these, by their turn, are predated by the microzooplankton (Azam et al., 1983; Bloem et al., 1989; Pomeroy, 1992; Deming \& Baross, 1993; Le Corre et al. 1996; Suzuki et al, 1996). Pomeroy (1992) described observations made in upwelling regions in North and South Africa, where, after isolated upwelling peaks, primary production showed a strong decrease, leading to a change in zooplankton feeding, which started to consume the microorganisms, thus closing its life cycle. This pattern fits perfectly to the Arraial do Cabo region.

Relationship between bacteria and remaining trophic levels is very complex and difficult to understand requiring deeper studies understand these trophic compartments. There are not many studies in 
Brazil regarding the assessment of this important trophic compartment. It is necessary that studies with this approach be developed in coastal and oceanic areas for the assessment and comprehension of the role of bacterioplankton in marine ecosystems.

\section{ACKNOWLEDGEMENTS}

We thank the Chemical Oceanography Team of the IEAPM for the chemical analyses and the Crew of the NpQ "Diadorim" for ship operations. Financial and logistic support provided by the Instituto de Estudos do Mar Alte. Paulo Moreira (IEAPM).

\section{REFERENCES}

Azam, F.; Fenchel, T.; Field, J. C.; Gray, J. S.; Meyer-Reil, L. A. \& Thingstad, F. 1983. The ecological role of watercolumn microbes in the sea. Mar. Ecol. Prog. Ser., 10:257-263.

Bloem, J.; Albert C.; Bär-Gillssen M. B.; Berman T. \& Cappeberg T. E. 1989. Nutrient cycling through phytoplakton, bacteria and protozoa, in selectively filtered Lake Vechten water. J. plankt. Res., 11(1):119131.

Deming, J. W. \& Baross, J. A. 1993. The early diagenesis of organic matter: Bacterial Ativity. Organic Geochemistry - Principles and Applications. New York and London, Plenum Press, p. 119-144.

Ducklow, H. W. \& Hill, S. M. 1985. The growth of heterotrophic bacteria in the surface waters of warm core rings. Limnol. Oceanogr., 30:239-259.

Ducklow, H.W.; Kirchman, D. L.; Quinby, H. L.; Carlson, C. A. \& Dam, H. G. 1993. Stoks and dynamics of bacterioplankton carbon during the spring bloom in the Eastern North Atlantic Ocean. Deep-Sea Res., II, 40(1/2): $245-263$.

Ferguson, R. L.; Buckley, E. N. \& Palumbo, A. V. 1984. Response of marine bacterioplankton to differential filtration and confinement. Appl. environ. Microbiol., 47:49-55.

Fuhrman, J. A.; Ammerman, J. A. \& Azam, F. 1980. Bacterioplankton in the costal euphotic zone: distribution, activity and possible relationships with phytoplankton. Mar. Biol., 60:201-207.

Gonzalez-Rodriguez, E. 1991. A ressurgência de Cabo Frio (RJ, Brasil): fertilidade e fatores limitantes da biomassa fitoplanctônica. Rev. Bras. Biol., 51:471-486.

Gonzalez-Rodriguez, E.; Valentin, J. L.; André, D. L. \& Jacob, S. A. 1992. Upwelling and downwelling at Cabo Frio (Brasil): comparison of biomass and primary production responses. J. plankt. Res., 14(2):289-306.

Joiris C.; Billen, G.; Lancelot, C.; Daro, M. H.; Mommaerts, J. P.; Bertels, A.; Bossicart, M.; Nijs, J. \& Hecq, J. H. 1982. A budget of carbon recycling in the Belgian Costal Zone: relative roles of zooplankton, bacterioplankton e benthos in the utilization of primary production. Neth. J. Sea Res., 16:260-275.

Kirchman, D. L.; Keil, R. G.; Simon, M. \& Welschmeyer, N. A. 1993. Biomass and production of heterotrophic bacterioplankton in the oceanic subartic Pacific. DeepSea Res., 40:967-988.
Le Corre, P., Wafar, M., L'helguen, S. \& Maguer, J. F. 1996. Ammonium assimilation and regeneration by sizefractionated plankton in permanently well-mixed temperature waters. J. Plankt. Res., 18(3):355-377.

Li, W. K. W.; Dickie, P. M.; Harrison, W. G. \& Irwin, B. D. 1993. Biomass and production of bacteria and phytoplankton during the spring bloom in the western North Atlantic Ocean. Deep-Sea Res. II, 40(1/2):307327.

Linley, E. A. S.; Newll R. C. \& Lucas M. I. 1983. Quantitative relationships between phytoplankton, bacteria and heterotrophic microflagellates in shelf waters. Mar. Ecol. Prog. Ser., 12:77-89.

Lorenzzetti, J. A. \& Gaeta, S. A. 1996. The Cape Frio Upwelling effect over the South Brazil bight northern sector shelf waters: a study using AVHRR images. Int. Arch. Photogr. Rem. Sens., 31(B7):448-453.

Malinsky-Rushansky, N. Z. \& Legrand, C. 1996. Excretion of dissolved organic carbon by phytoplankton of different sizes and subsequent bacterial uptake. Mar. Ecol. Prog. Ser., 132:249-255.

Martin, J. H.; Fitzwater, S. E.; Gordon, S. E. \& Hunter, R. M. 1993. C. N. and Carbon-Nitrogen flux studies during the JOGOFS North Atlantic Bloom Experiment. Deep-Sea Res. II, 40:115-134.

Mcmanus, G. B. \& Peterson, W. T. 1988. Bacterioplankton production in the nearshore zone during upwelling off central Chile. mar. Ecol. Prog. Ser., 43:11-17.

Pomeroy, L. R. 1992. The microbial food web. Oceanus, 35(3):28-35.

Richard, T. A. \& Thompson, T. G. 1952. The estimation and characterization of the estimation of plankton pigments. J. mar. Res., 11:156-172.

Romam, M. R.; Caron, D. A.; Kremer, P.; Lessard, E. J.; Madin, L. P.; Malone, T. C.; Napp, J. M.; Peele, E. R. \& Youngbluth, M. J. 1995. Spatial and temporal changes in the partitioning of organic carbon in the plankton community of the Sargasso Sea off Bermuda. Deep-Sea Res., 42:973-992.

Scor-Unesco 1966. Determination of phytosynthetic pigments in sea-water. Monogr. oceanogr. Methodol., U.N.1:69 p.

Sherr, E. B.; Sherr B. F. \& Sigmon, C. T. 1999. Activity of marine bacteria under incubated and in situ conditions. Aquat. microbiol. Ecol., 20:213-223.

Smith D. C. \& Azam, F. 1992. A simple, economical method for measuring bacterial protein synthesis rates in seawater using ${ }^{3} \mathrm{H}$-Leucine. Mar. microb. Food Webs, 6(2):107-114.

Sorokin, Y. I. \& Mikheev, V. N. 1979. On characteristics of the Peruvian upwelling ecosystem. Hydrobiologia, 62:65-189.

Sorokin, Y. I.; Sorokin, P. Y. \& Mamaeva, T. I. 1996. Density and distribution of bacterioplankton and planktonic ciliates in the Bering Sea and North Pacific. J. plankt. Res., 18(1)1-16.

Steeman Nielsen, E. 1952. The use of radio-active carbon $\left({ }^{14} \mathrm{C}\right)$ for mesuring organic production in the sea. J. Cons. per. int. Explor. Mer., 18:117-140.

Strickland J. D. \& Parsons, T. R. 1972. A practical handbook of sea water analysis. Bull. Fish. Res. Can., 167:1-310.

Suzuki, M. T. 1999. Effect of protistan bacterivory on costal bacterioplankton diversity. Aquat. microbiol Ecol., 20:261-272. 
Suzuki, M. T.; Sherr, E. B. \& Sherr B. F. 1996. Estimation of ammonium regeneration efficiencies associated with bacterivory in pelagic food webs via ${ }^{15} \mathrm{~N}$ tracer method. J. plankt. Res., 18(3):411-428.

Tarapchak, S. J. \& Moll, R. A. 1990. Phosphorus source for phytoplankton and bacteria in Lake Michigan. J. plankt. Res., 12(4):743-758.

Thingstad, T. F.; Riemann, B. O.; Havskum, H. \& Garde K. 1996. Incorporations rates and biomass content of $\mathrm{C}$ and $\mathrm{P}$ in phytoplankton and bacteria in Bay of Aarhus (Denmark) June 1992. J. plankt. Res., 18(1):97-121.

Thingstad, T. F.; Havskum, H.; Kaas, H.; Nielsen, T. G.; Riemann, B.; Lefevre, D. \& Williams P. J. B. 1999. Bacteria-protist interactions and organic matter degradation under P-limited conditions: analysis of na enclosure experiments using a simple model. Limnol. oceanogr., 44(1):62-79.

Valentin, J. L. \& Moreira, A. P. 1978. A matéria orgânica de origem zooplanctônica nas águas de ressurgência de Cabo Frio (Brasil). An. Acad. Bras. Ciênc., 50(1):103112.
Valentin, J. L. 1984. Spatial structure of the zooplankton community in the Cabo Frio Region (Brazil) influenced by coastal upwelling. Hydrobiologia, 113:183-199.

Valentin, J. L. 1994. A ressurgência fonte de vida dos oceanos. Ciência Hoje, 18(102):19-25.

Vinogradov, M. E. \& Shushkina, E. A.1978. Some development patterns of plankton communities in the upwelling areas of the Pacific Ocean. Mar. Biol., 48:357366.

Yentsch, C. S. 1990. Estimates of "new production" in the Mid-North Atlantic. J. plankt. Res., 12:717-734.

(Manuscript received 24 September 2002; revised 25 June 2003; accepted 17 November 2003) 